\title{
Review of Craig Oliver Unleashing Demons: the Inside Story of Brexit
}

\section{Timothy Whitton}

\section{CpenEdition}

\section{Journals}

Electronic version

URL: http://journals.openedition.org/rfcb/1314

DOI: $10.4000 /$ rfcb.1314

ISSN: 2429-4373

\section{Publisher}

CRECIB - Centre de recherche et d'études en civilisation britannique

\section{Electronic reference}

Timothy Whitton, «Review of Craig Oliver Unleashing Demons: the Inside Story of Brexit », Revue Française de Civilisation Britannique [Online], XXII-2 | 2017, Online since 30 May 2017, connection on 24 April 2019. URL : http://journals.openedition.org/rfcb/1314 ; DOI : 10.4000/rfcb.1314

This text was automatically generated on 24 April 2019

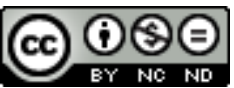

Revue française de civilisation britannique est mis à disposition selon les termes de la licence Creative Commons Attribution - Pas d'Utilisation Commerciale - Pas de Modification 4.0 International. 


\title{
Review of Craig Oliver Unleashing Demons: the Inside Story of Brexit
}

\author{
Timothy Whitton
}

\section{REFERENCES}

Craig OLIVER, Unleashing Demons: the Inside Story of Brexit, London, Hodder \& Stoughton, 2016, 420 pages, ISBN - 978147365245 3, 25 euros.

1 Craig Oliver was David Cameron's Director of Politics and Communications and this part diary, part memoir fly-on-the wall account of the six months that led up to the Brexit takes readers to the heart of the Remain campaign as it unfolded on a day to day basis. Oliver's presence beside the Prime Minister, often from dawn to dusk, sheds an extremely intimate light on the way the British government dealt with the referendum and given the tight schedules that the main actors had, it is worth wondering how the author found time to write this book at all. Craig Oliver is definitely on the "Remain" side and feels that "Leave" based their campaign on deceit and a series of untruths that the different medias - and most disappointingly the BBC - let them get away with. Through it all, oliver shows utter devotion to his boss and the Remain camp's patriotism, underlining the fact that leaving the EU has been a nagging antagonism for decades: it just reared its ugly head during Cameron's watch and he was brave enough to deal with it.

2 The book opens with the climax to the referendum vote and then returns to a month by month account - each one being broken down into subparts to capture the spirit of events - of the six-month period from January to June 2016. Oliver's overarching thesis is that the Leave campaign managed to latch on to the 3 million voters who are unreachable by any reasonable campaign, but who are quite willing to punish the political establishment at the drop of a hat. They were thus quite ready to lap up the dodgy Leave propaganda peddled by the vociferous tabloids and their visceral wariness of politicians was exacerbated by the rift between top members of the British cabinet. The "Stronger In" campaign failed to see this and remained faithful to a form of deontology that made 
them feel good about their work but deprived them of the opportunities to make sufficient inroads into their rivals' demolition work. By playing too much by the book, opponents were simply not nailed as they could have been for backing up the Leave campaign's most questionable statements. Nor were they questioned enough about their post referendum ambitions including the possibility that they were quietly forming an alternative government ready to take over when Cameron left.

Craig Oliver devotes considerable space to the issue of collective cabinet responsibility which was waived during the campaign, but only after renegotiation. It was essential that the government be seen to be docking clearly with one side - or the other - of the campaign, but disagreement within the cabinet gave the overall impression that the whole thing was an absurd shambles. All in all, $\mathrm{n}^{\circ} 10$ comes across as being unprepared for the referendum given the utter amazement expressed by the author that some cabinet members should suddenly turn their coats and be disloyal to the Prime Minister. Yet the referendum was never designed to be about Cameron hence his early statement that he would not stand down should Brexit win. Oliver continually underlines Cameron's highly motivated personal contribution to the course of events and his fear that the campaign could have been blown off course because of the "Blairmore" affair is palpable. Cameron's team could only look on helplessly as Iain Duncan Smith chose to resign ostensibly to state his case about planned benefit cuts while Michael Gove, the Prime Minister's close friend, was portrayed as being even more cut throat by playing an elegantly despicable role in the leave campaign.

In the meantime, Boris Johnson could easily have bumbled his way into the Remain camp given that he constantly gave the impression of not really wanting to leave the $\mathrm{EU}$ and that come what may, there would always be room to repair Brexit. Or perhaps Johnson and his supporters believed that with the threat of Brexit looming even larger, Europe would come running to offer even better conditions than those negotiated by Cameron in January? Remaining was portrayed as a sign of weakness whereas leaving showed the romantic strength of convictions and that Britain could and should stand up for herself as she had done in a not such a distant past. Yet for Craig Oliver and the Prime Minister's team, there was no doubt whatsoever that Brexit would not lead to any further negotiations and it was up to them to get this message across. They emphasised the "leap in the dark" that Brexit would entail whereas Bremain quite clearly meant reducing bureaucracy, protecting the pound and reducing benefits to make Britain less attractive for migrants, to name but a few advantages it had to offer. Yet in doing so, they attracted even more attention to these issues, as if the EU could be reduced to them and very little else.

5 Unpreparedness went beyond the rift within the Cabinet as the author explains that when the referendum was called in January for June, this left only six months to explain to voters the intricacies of the European Union. More time could have avoided polarising the debate on such simple issues as migrants, asylum seekers and welfare. Far too much headline attention was paid to them thus maximising their publicity during the campaign. If debate had begun in 2013 when the referendum was first promoted by Cameron, the government would have been able to devote far more time to coaxing the British public into a better relationship with Europe. As things stood, by hinging the referendum round the renegotiation deal, time was short and the simpler issues could more easily be thrust to the fore. In light of this, the "out" campaign had a far clearer message to deliver on British sovereignty, whereas "in" was seen to be fudging things by 
trying to have the best of both worlds: the economic advantages of remaining in the EU while remaining out of the Eurozone - and thus being less affected by potential bailouts -, and the Schengen "no borders" agreement. The message was sincere but not clear enough for an electorate that contained enough disappointed voters ready to pounce on the slightest signs of weakness to punish rather than support.

Craig Oliver dwells on the Labour Party's contribution to the campaign and highlights their lukewarm support for Remain. This was partly due to internal weaknesses caused by their highly contested leadership providing yet another quandary for Cameron: to what extent could he continue to berate his political opponent while expecting him to provide support for staying in the EU and above all get Labour voters to turn out? Jeremy Corbyn was faced with his own conflict of loyalties given that a Tory war could only improve Labour's chance of returning to power. But, at the same time, his political duty was to back Remain without giving the impression that he would not be averse to seeing the campaign veer towards a wider referendum used to assess the government's record, especially in light of the austerity measures it had implemented. Oliver explains just how nerve racking it had become to keep a tight control over communication - his speciality within the rainbow coalition that the government was indeed seeking so hard to maintain between Labour, the Liberal Democrats, the Greens and the TUC even without the added problems of infighting within the Conservative Party that would more than likely depress turnout to the advantage of Leave. Rumours that the Queen backed Brexit were also a serious mishap but they were counterbalanced to some extent by President Obama's making it quite clear that the United States would prefer to deal with a block rather than an individual country.

Obama's visit was indeed deemed to be a watershed moment in the referendum campaign but as the date drew nearer, it seemed as if the two campaigns had been whittled down to a straight contest between immigration on the leave side, and the economy on the other. Remain tried desperately to make its case that dealing with immigration by crippling the economy was ludicrous and for a few days, this argument seemed to hold enough water for victory to seem possible. The tragic murder of MP Jo Cox meant a suspension of campaigning and a deal of soul searching into what the referendum was really all about but Oliver simply reminds readers that given the overall context, no one really knew how to react to her death.

One of the most interesting sections of the book is devoted to Oliver's personal conclusions after the Brexit decision and a breakdown of the statistics. He felt his side had not had a credible enough answer to immigration which gave angry voters ample opportunity to express their instinctive dislike of the EU. The referendum was also a proxy to express anger at a whole swathe of issues many of which had nothing to do with Europe all the more so as public relations had been insufficient to steer people away from the nonsense that was peddled relentlessly by a large part of the press. His side had lacked a core message possibly because of the difficulty they had had in bringing together so many different partners under one banner. Lastly, Bremain's arguments were far less convincing quite simply because there were politicians behind the decisions who are mistrusted by the voting public. On the other side, Brexit had a core message and according to Craig Oliver, they lied.

Unleashing Demons can almost be read as a political thriller given that nearly every page holds its own anecdote, event, episode or story. It's an exciting read if you are interested in the fine details of just how frantic government machinery became during the 
referendum campaign. Yet Craig Oliver's devotion vis-à-vis his boss prevents him from asking some of the fundamental questions that he could have at least attempted to answer beginning with why organise a referendum in the first place given that there was a distinct possibility that it would produce such a momentous decision in the history of Great Britain? To justify the course of events by suggesting that it was quite simply Cameron's call and he made it is unsatisfactory but Oliver is a spin doctor and this book is about spin. The real issues at stake are buried beneath the communication skills of those involved and readers are literally swamped with names of people whom they know next to nothing about. The spin and namedropping may be somewhat overwhelming but the insights into how $\mathrm{n}^{\circ} 10$ dealt with the referendum campaign on a daily basis for six months mean that this book is a valuable read not only for scholars of European studies but members of the public who want a vivid and exciting inside account of Brexit.

\section{AUTHORS}

TIMOTHY WHITTON

Université Clermont-Auvergne 